\title{
Nurtured and sorrowful: Positive and negative emotional appeals in COVID-19 themed brand communications
}

\author{
Mensa, $\mathrm{M}$. \\ Instituto de Comunicación Social, Universidad Austral de Chile. \\ marta.mensa@uach.cl (corresponding author) \\ Orcid: 0000-0002-8239-3674 \\ Vargas-Bianchi, L. \\ Escuela de Posgrado, Universidad de Lima. \\ Ivargas@ulima.edu.pe \\ Orcid: 0000-0002-9027-7673
}

Citation:

Mensa, M. \& Vargas-Bianchi, L. (2020). Nurtured and sorrowful: Positive and negative emotional appeals in COVID-19 themed brand communications.

\begin{abstract}
This study aims to analyze emotional appeals in brand advertisements themed in COVID-19 during the immediate months after the World Health Organization declared the coronavirus outbreak as a pandemic. The study focused on the frequencies of use of positive and negative emotional appeals in ad contents, and on the concurrent combinations of those appeals. Researchers conducted a content analysis among ads included in an online archive, selected by industry professionals for their creative quality. The results reveal a preference for positive emotions, as nurturance and affiliation show the highest frequency of use. These appeals, along with sorrow, nostalgia and excitement, were preferred to be used concurrently. Research findings are consistent with the literature, and lead to future examination of emotional appeals in advertising under stressful and uncertain circumstances.
\end{abstract}

Keywords: emotional appeals, advertising, COVID-19, communication.

\section{Introduction}

The coronavirus (COVID-19) outbreak started in December 2019 in the Chinese city of Wuhan (Mejova \& Kalimeri, 2020). Since then, worldwide health has been threatened as the virus spread from one continent to another. This circumstance increases the levels of stress that people encounter as they face health, economic and emotional risks, in concomitance with the difficulty of anticipating events in the short term. Anxiety, depression and stress related to COVID-19 have been reported (Cowan, 2020; Huang \& Zhao, 2020; Fitzpatrick, Harris \& Drawve, 2020). In this scenario, emotions may run high and play an important role in the configuration of consumer's attitudes and judgments (Royo-Vela, 2005). According to the law of apparent reality, the more vivid the content of an advertisement, the more intense and real will be the emotions perceived by the consumer (Frijda, 1988). For instance, if COVID-19 has generated emotions such as fear or sorrow, ad messages conveying these affections may intensify the consumers' emotional experience and further stress them 
(Kemp, Kennett-Hensel \& Kees, 2013; Poels \& Dewitte, 2019; Royo-Vela, 2005). Ad practitioners prefer to match the emotions identified in target users with those in the communication content, expecting this will drive individuals' engagement with the brand (Mogaji, 2016). Yet, advertisers ought to be cautious when using emotions during difficult circumstances, as messages can heighten a sense of anxiety and stress amongst their buyers and other subjects (Nabi, 2003).

The academic literature encompasses studies about the use of emotions in advertisements. However, the adoption of these resources in ads subjected on a phenomenon of such magnitude is unprecedented. It applies to deepen the knowledge concerning the use of emotional appeals during stressful circumstances such as the current pandemic. This study aims to analyze these appeals in advertisements from around the world themed in COVID-19 and produced during the immediate months after the World Health Organization declared the coronavirus outbreak as a pandemic. It does so in the following research questions:

RQ1: What were the frequencies of use of positive and negative emotional appeals featured in COVID-19 themed advertisements during the first months of the pandemic?

RQ2: What were the preferred combinations of emotional appeals used by advertising agencies in the COVID-19 themed ad contents during the early period of the pandemic?

RQ3: How did the frequencies of use of emotional appeals evolve during the initial months of the pandemic?

Researchers carried out a quantitative content analysis, providing a comprehensive study related to each of the research questions. In the years to come, emotions will gain prominence in brand communications (Kotler, Kartajaya \& Setiawan 2017). Parvathi and Mariselvi (2017) predict the appearance of Web 4.0 in 2020-2030, which will relate to the concept of Emotive Web, where individuals allow themselves to share their emotions more openly through social networks (Almeida, 2017; Polanska, 2014). For example, the social network Facebook introduced new emojis as a means for its users to express their emotional states (e.g. love, anger or sadness) (Tian et al., 2017). As the resource to emotions will proliferate in marketing contents in the short and medium term, it is convenient to continue deepening the knowledge about its use.

\section{Literature review}

Appeals are intentional resources to engage with potential customers' needs, wants, or interests (Bathia, 2019). They are a means for motivating subjects' propensity to purchase the advertised goods or services, by driving interest to the product, building long-term loyalty, and creating a sense of belonging to a brand community (Bathia, 2019; Pinto \& Yagnik, 2016). The academic literature addresses two types of advertising appeals: rational and emotional (Kotler 2003; Pinto \& Yagnik, 2016). Rational appeals are driven by information processing on a conscious level, while emotional appeals are so by the unconscious mind or the persons' feelings (Bhatia, 2019). Rational appeals focus on the individual's functional needs and emphasize objective features of the product and the service (Rochford, 2011; Zhang et al., 2014). These claims often focus on the product's utilitarian 
benefits, such as pointing to a goods' superior quality, value, performance and reliability (Johar \& Sirgy, 1991). Emotional appeals try to raise either negative or positive emotions that prompt consumers to ease brand recall and promote purchasing decisions (AlbersMiller \& Stafford, 1999; Kotler \& Armstrong, 1991; Marchegiani \& Phau, 2013; Zhang et al., 2014).

Using positive emotional appeals assumes that consumers are emotionally stimulated, and so, marketers try to stimulate this variable to carry out their goals (Pinto \& Yagnik, 2016) (see Table 1). Marketing and ad executives seek to make the consumer feel good about the product by linking positive emotions to it, resulting in increased brand likeability and strengthened positive attitudes related to the brand (Hornik, Ofir \& Rachamim, 2017; Panda, Panda \& Mishra, 2013). Bathia (2019) identified linguistic markers and strategies in emotional ads and found that the positive emotional grounding is critical for brand recognition, the development of a positive attitude towards the brand, and customer loyalty. Lin (2011) conducted a study to find the impact of positive emotional appeals used in advertising on attitudes and purchase intentions. He reported that emotional appeals do influence individuals' attitudes toward the ad. After examining positive emotional appeals in tourism TV commercials, Li (2019) argued that adventure and excitement are the most effective appeals to relate with consumers. Further authors found that positive appeals can also enhance the consumer's attention (Chang \& Chang, 2014; Czarnecka \& Mogaji, 2019; Hornik, Ofir \& Rachamim, 2017; Panda, Panda \& Mishra, 2013; Wu et al., 2018).

Other studies compare positive and negative emotional appeals in ad contents. For example, Coleman, Royne \& Pounders (2020) focus on guilt and pride appeals in causerelated marketing messages. They found that pride appeals are more effective for promoting cause-related actions in individuals, while guilt works in promoting actions and prevention awareness. Czarnecka \& Mogaji (2019) examined positive and negative emotional appeals in advertisements for financial loans. Their results convey that these ads use positive emotions such as relief, security or excitement, and that negative emotional appeals were employed occasionally. In their review of the literature, Czarnecka \& Mogaji (2019) identify 15 types of positive and negative emotional appeals used in advertising. Wu et al. (2018) analyzed a sample of positive and negative emotional appeals in click intention on digital advertisements. Their findings showed a powerful effect related to positive emotions, and a weak one toward negative ones.

Table 1. Positive emotional appeals

Type of emotional appeal Concepts comprised Authors in academic literature
(Czarnecka \& Mogaji,

\begin{tabular}{lll}
\hline Adventure & $\begin{array}{l}\text { Boldness, daring, bravery, courage, seeking adventure } \\
\text { or, thrills. }\end{array}$ & $\begin{array}{l}\text { Hetsroni (2000); Mogaji (2016); } \\
\text { Pollay (1983). }\end{array}$ \\
Affiliation & $\begin{array}{l}\text { To be social, bond in friendship, companionship, } \\
\text { cooperation, reciprocity; to conform to social norms, } \\
\text { have manners, social graces, and decorum, tact and } \\
\text { finesse. }\end{array}$ & Pollay (1983).
\end{tabular}




\begin{abstract}
Beauty
Beauty is a cognitive process accompanied by continuously upgrading affective states that results are appraised as an aesthetic emotion and/or judgment.
\end{abstract}

Excitement

Nurturance

Popular

Relief (Relaxation)

Security

Sex

Pride

Nostalgia

Youth
Emotional, pleasure, satire, wit, relief, positive mood, it provokes amusement, joy and fun.

Nurturance appeal was defined as one which evoked the idea of caretaking, such as parents caring for their child's health and well-being.

Commonplace, customary, well-known, conventional. regular, ordinary, normal, standard, typical, universal, general, every day.

Relief can be conceptualized as warmth, a highly positive emotion that people enjoy in their relationships with family or friends, involving a moderate level of arousal.

Confident, secure, possessing dignity, self-worth, selfesteem, self-respect, peace of mind.

Emotional, physiological arousal, sensation, fantasy, dreams, self-esteem.

Pride is a feeling of satisfaction, delight, or pleasure in something one has achieved and/or one is able to do. Individuals experience pride when they appraise the self as being responsible for a positive outcome.

A preference (general liking, positive attitude, or favorable affect) toward objects (people, places, or things) that were more common (popular, fashionable, or widely circulated) when one was younger (in early adulthood, in adolescence, in childhood, or even before birth.
Hagtvedt \& Patrick (2008); Leder et al. (2004); Zarzosa \& Huhmann (2019).

Chang \& Chang (2014); Czarnecka \& Mogaji (2019); Hornik, Ofir \& Rachamim (2017); Li (2019).

Bleakley et al. (2015); MeadowsOliver \& Hendrie (2013).

Hetsroni (2000); Mogaji (2016); Pollay (1983).

Aaker, Stayman \& Hagerty (1986); Abele \& Gendolla (1999); Faseur \& Geuens (2006).

Hetsroni (2000); Mogaji (2016); Pollay (1983).

Hornik, Ofir \& Rachamim (2017); Reichert \& Lambiase (2014); Vargas-Bianchi \& Mensa (2020).

Coleman, Royne \& Pounders (2020); Decrop \& Derbaix (2010).

Havlena \& Holak (1991); Holbrook \& Schindler (1991); Marchegiani \& Phau (2013); Stern (1992)

Hetsroni (2000); Mogaji (2016) Pollay (1983).

The presence of negative emotional appeals is smaller among advertising messages, as research reveals that positive ones have a wider range of marketing benefits (Czarnecka \& Mogaji, 2019; Deborah \& Nicole, 2009; Dens \& De Pelsmacker, 2010; Zheng, 2020) (see Table 2). The literature is divided about the effectiveness of negative emotional appeals, some authors assert that they might produce negative associations with the brand (Berger \& Milkman, 2012; Evans, Adamo \& Czarnecka, 2019), while others explain that negative feelings can bring good advertising appraisal and attitudes towards the product (Brennan \& Binney, 2010; Coleman, Royne \& Pounders, 2020; Coulter \& Pinto, 1995; Grossman \& Wood, 1993). Studies even suggest that sometimes messages featuring negative appeals are more effective than those containing positive ones (Basil, Ridgeway \& Basil, 2006; Giachino et al., 2017; Kemp, Kennett-Hensel \& Kees, 2013; Krishen \& Bui, 2015; Wang, 2008). For example, guiltiness can work for charities and nonprofits advertisements, as Kemp, Kennett-Hensel \& 
Kees (2013) remarked, that feelings of guilt promote the intention to donate. Consistent research shows that guiltiness and sorrow are emotional appeals that stimulate a desire to help others (Basil, Ridgeway \& Basil, 2006; Wang, 2008). Another example relates to fear, which has been reported to prompt the purchase of healthy products, as Krishen \& Bui (2015) note. They found that, after seeing pictures of obese bodies in advertisements, participants increased their preference for these products after fear of obesity. Giachino et al. (2017) suggested that fear was effective in reducing high-speed driving when used in advertising targeted to drivers.

The studies claim that emotional appeals can backfire when consumers perceive them as manipulative (Brennan \& Binney, 2010; Coleman, Royne \& Pounders, 2020; Coulter \& Pinto, 1995; Garfin, Silver, \& Holman, 2020). Brennan \& Binney (2010) explored guiltiness in advertising, they found that moderate or low-level appeals may connect with consumers, but if used in greater intensity guiltiness could be perceived as a blatant manipulation attempts and may cause responses like anger, offense, or irritation. Drakulich (2015) found that the excessive use of negative emotions in advertising may even produce mental and physical health problems, such as social withdrawal from others, and engaging in unnecessary social avoidance and protective behaviors.

Table 2. Negative emotional appeals and description.

\begin{tabular}{lll}
$\begin{array}{l}\text { Type of emotional } \\
\text { appeal (Czarnecka \& } \\
\text { Mogaji, 2019) }\end{array}$ & Concepts comprised & Authors in academic literature \\
\hline Fear & $\begin{array}{l}\text { Emotional, anxiety, tension, danger, threat } \\
\text { that people have when facing risks or crisis. }\end{array}$ & $\begin{array}{l}\text { Ahorsu et al. (2020); Drakulich (2015); Giachino et } \\
\text { al. (2017); Krishen \& Bui (2015); Rhodes (2015); } \\
\text { Zheng (2020). }\end{array}$ \\
Guilt & $\begin{array}{l}\text { Individuals experience guilt when they feel } \\
\text { their behavior has transgressed a personal or } \\
\text { social moral standard }\end{array}$ & $\begin{array}{l}\text { Basil, Ridgeway \& Basil (2006); Brennan \& Binney } \\
\text { (2010); Coleman, Royne \& Pounders (2020); Kemp, } \\
\text { Sennett-Hensel \& Kees (2013); Wang (2008). }\end{array}$ \\
& $\begin{array}{l}\text { Sadness is an emotional response when } \\
\text { people suffer from separation, loss and failure. }\end{array}$ & $\begin{array}{l}\text { Basil, Ridgeway \& Basil (2006); Durkin et al. (2018); } \\
\text { Wang (2008); Zheng (2020). }\end{array}$
\end{tabular}

\section{Methods}

To discuss the research questions, researchers performed a quantitative content analysis. In this method, messages are the phenomena to be examined. This analysis distinguishes the text as a reality produced in a way that has a significance for another person (Krippendorff, 2019). This method allows to show frequencies and patterns within the message content, making it adequate for this researches goal. An a priori coding analysis was carried out. In this design, codes are established deductively and are then applied by coders (Neuendorf, 2018).

Sample selection. Researchers extracted the studied advertisements from the digital archive "Ads of The World". This website receives the creative work sent by advertising agencies and other professional sources from around the world, whose authors consider they are of prime quality, about their creativity message, copy, art direction or similar accomplishments. In 
March 2020, this catalog opened a special section for ads produced because of the coronavirus pandemic (COVID-19 Ads Collection). TV and print ads were chosen for the analysis, because this format comprises most of the work uploaded to the catalogue. The inclusion criteria for the selection of ads was: (i) they must be made by a professional advertising agency, (ii) they must be formatted for audiovisual or print media, (iii) it must advertise a branded product or service, (iv) if it includes a copy it must be written using Latin alphabet, (v) they should have been uploaded to the digital archive between March and June 2020. The sample comprised 376 advertisements. Two ads were excluded as they used a non-Latin alphabet.

Coding unit and categories. Individual print and TV advertisements were defined as the coding units. Researchers used the inventory of emotional appeals proposed by Czarnecka \& Mogaji (2019) as the set of a priori categories for analysis. These 15 appeals are divided into two types: positive and negative emotional appeals, as exhibited in Table 3. Researchers analyzed each of these categories in the textual and / or graphic elements of each unit.

\begin{tabular}{|c|c|c|}
\hline Type of emotional appeal & Emotional appeals & \\
\hline \multirow{6}{*}{ Positive } & Adventure (Escape, Freedom) & Relief (Relaxation) \\
\hline & Affiliation & Security \\
\hline & Beauty (Aesthetics, Ornamental) & Sex \\
\hline & Excitement (Humour, Happiness, Joy) & Pride \\
\hline & Nurturance & Nostalgia \\
\hline & Popular & Youth \\
\hline Negative & $\begin{array}{l}\text { Fear (Danger, } \\
\text { Embracement) }\end{array}$ & $\begin{array}{l}\text { Sorrow (Grief, } \\
\text { Suffering) }\end{array}$ \\
\hline
\end{tabular}

Coding procedure and intercoder reliability. Both researchers independently coded the sampled ads. The codebook was constructed based on the categorization of emotional appeals by Czarnecka \& Mogaji (2019) (Table 3, see also Tables 1 and 2). The coding sheets were also prepared and discussed by both researchers. They trained by conducting preliminary coding with a small sample of ads to ensure understanding of the codes' definitions and consistency of the coding procedures established in the codebook. Discrepancies in the coding were discussed and re-assessed. After two rounds of training, the intercoder reliability obtained using Cohen's kappa was 0.85, suggesting almost perfect agreement.

\section{Results}

The number of ads analyzed from March to June was $\mathrm{N}=376$. The selection of ads that incorporated at least one emotional appeal was $n=208$, revealing that $55.3 \%$ of advertisements included in the sample comprised this resource. Most of those ads used positive appeals (72\%), a smaller number employed a mix of positive and negative appeals (21\%), and a few advertisements only used negative emotional appeals (7\%). The data reveals that the appeals with highest use frequency were Nurturance, Affiliation, Sorrow, Nostalgia, Excitement and Pride (Figure 1). 


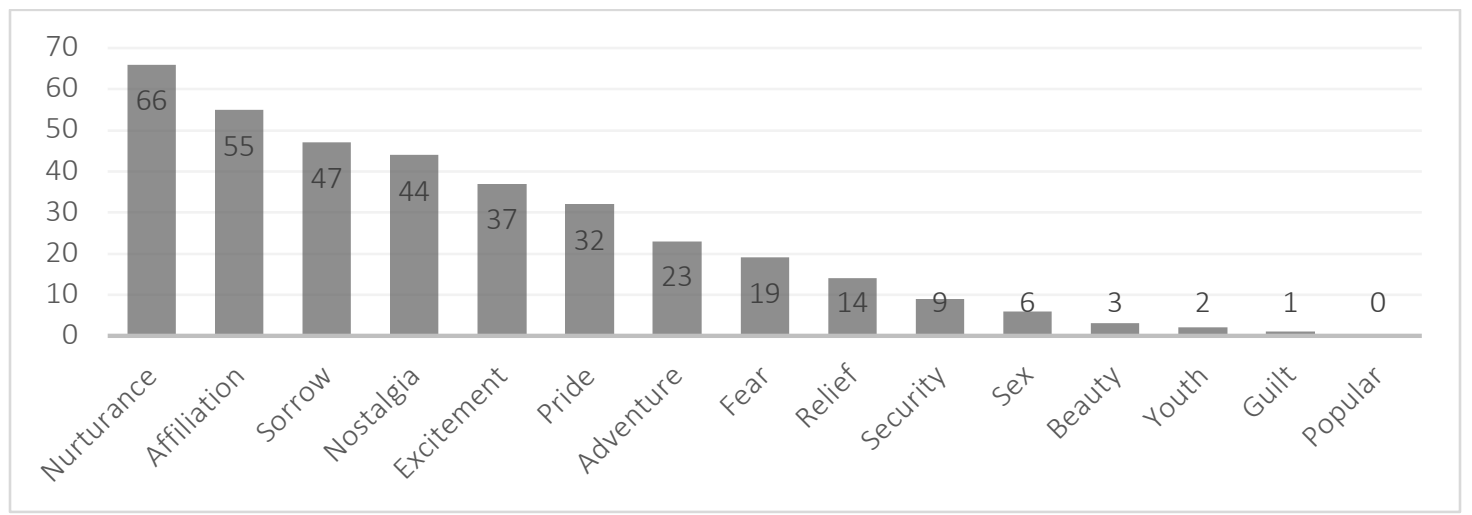

Figure 1. Percentage of frequency of use of emotional appeals in advertisements

Regarding the concurrency of emotional appeals in each advertisement, 70 ads featured 2 appeals concurrently; 39 ads featured 3 appeals; 6 ads featured 4 appeals, and 3 ads featured 5 emotional appeals simultaneously ( $n$ ads using concurrent emotional appeals = 118) (Table 4). The categories nurturance, affiliation, sorrow and nostalgia reveal the highest concurrent frequencies (Figure 2). Preferred combinations were nurturance and affiliation (featured in 36 concurrent opportunities); sorrow-nostalgia (17 opportunities); nurturance-pride (16 opportunities); nurturance-nostalgia, and nurturance- sorrow, and fear-sorrow (14 opportunities); nostalgia-affiliation (12 opportunities) (Figure 3).

Table 4. Percentage of concurrent emotional appeals featured in ads

\begin{tabular}{|c|c|c|c|c|c|c|c|c|c|c|c|c|c|c|}
\hline $\begin{array}{l}\text { Emotional } \\
\text { appeal }\end{array}$ & $\begin{array}{l}\text { Nurtu- } \\
\text { rance }\end{array}$ & $\begin{array}{l}\text { Affil- } \\
\text { iation }\end{array}$ & $\begin{array}{l}\text { So- } \\
\text { rrow }\end{array}$ & $\begin{array}{l}\text { Nos- } \\
\text { talgia }\end{array}$ & $\begin{array}{l}\text { Excite- } \\
\text { ment }\end{array}$ & Pride & $\begin{array}{l}\text { Adven- } \\
\text { ture }\end{array}$ & Relief & $\begin{array}{l}\text { Secu- } \\
\text { rity }\end{array}$ & Fear & Beauty & Youth & Sex & Guilt \\
\hline $\begin{array}{l}\% \text { of } \\
\text { frequency of } \\
\text { concurrent } \\
\text { featuring }\end{array}$ & 19.3 & 16.2 & 13.9 & 12.8 & 8.4 & 7.8 & 5.1 & 4.7 & 3.7 & 3.7 & 2.4 & 1.0 & 0.7 & 0.3 \\
\hline
\end{tabular}

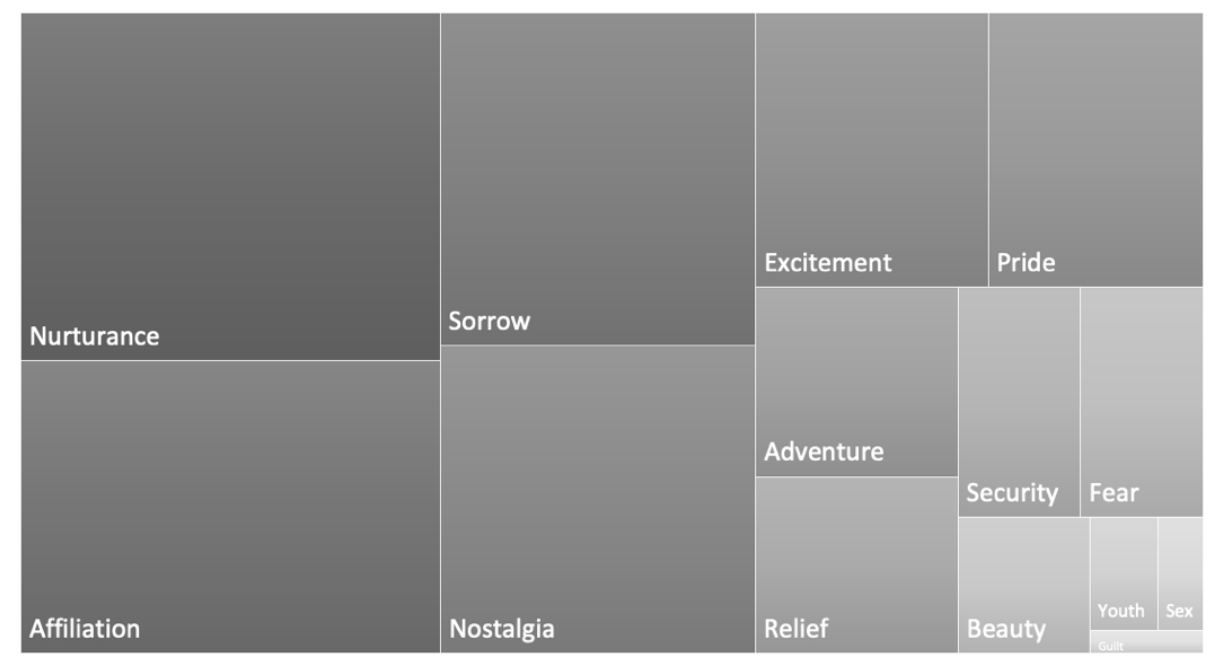

Figure 2. Hierarchy chart exhibiting the concurrent frequencies of emotional appeals featured in sampled advertisements. 


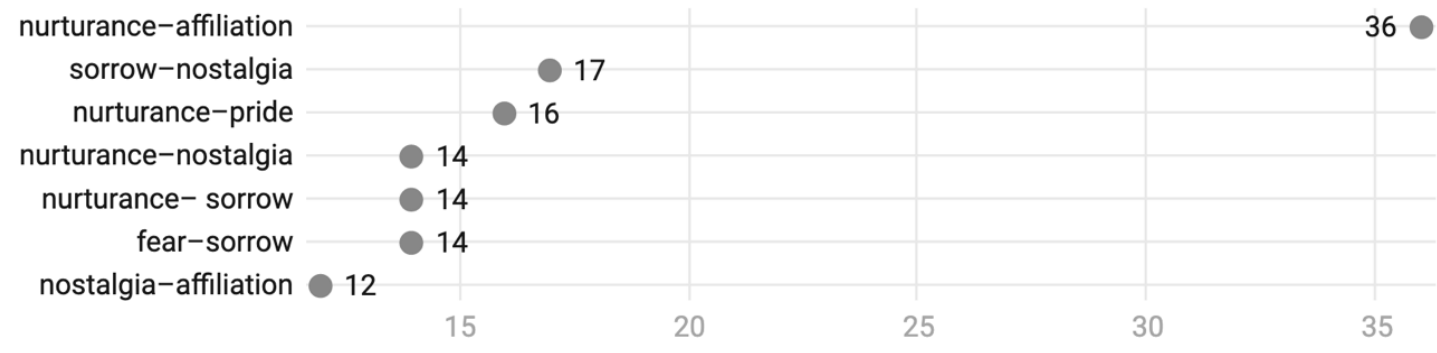

Figure 3. Number of emotional appeal concurrencies in COVID-19 themed brand advertisements.

Regarding the evolution in the recurrence of use of emotional appeals in the studied period, the data shows abrupt increases in April, and May compared to the other months (Table 5). This data showed a similar tendency between the number of ads per month and the frequency of use of emotional appeals during the same period. The frequency of use of these appeals and the number of adverts uploaded to the catalog per month were positively correlated, $r(374)=.78, \mathrm{p}<.05$.

About the recurrence of positive and negative appeals during the researched time span, the data revels a higher presence of positive appeals, with a peak in May, while negative appeals evidence its highest use during May. Figure 4 shows the detailed evolution of both types of emotional appeal over the four months period.

Table 5. Frequency of use of emotional appeals per month and descriptive statistics

\begin{tabular}{llllllll}
\hline $\begin{array}{l}\text { Months and descriptive } \\
\text { statistics }\end{array}$ & March & April & May & June & Mean & SD \\
\hline No. of ads in sample & 42 & 168 & 147 & 19 & 94.3 & 64.2 \\
\hline $\begin{array}{l}\text { Frequency of feature of } \\
\text { emotional appeals in ads }\end{array}$ & 20 & 144 & 166 & 38 & 92 & 63.8 \\
\hline
\end{tabular}

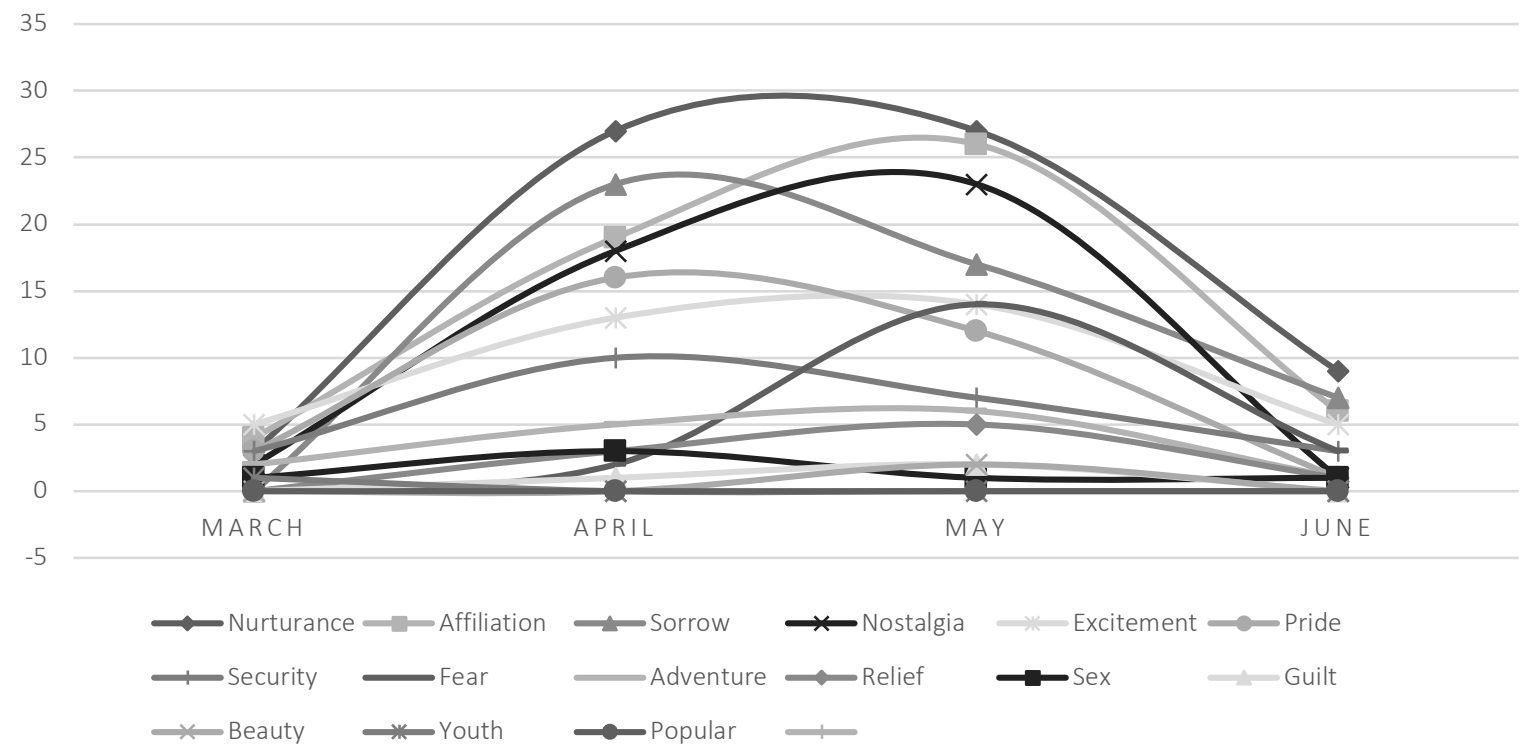

Figure 4. Evolution of the frequency of use of use of emotional appeals over the studied period. 


\section{Discussion}

This study provides a comprehensive analysis of positive and negative emotional appeals featured in early COVID-19 themed advertisements. The results show an increase in the usage of emotional appeals as time passed since the beginning of the outbreak. This rise was characterized by the concurrent use of different emotional appeals, which may indicate an eagerness to enhance the strength of the messages, or mirror the mixed emotions that individuals experienced in the uncertainty of the first months of the pandemic.

Nurturance was the emotional appeal with the highest frequency of use evidenced among the sampled ads. This positive appeal is defined as one which evokes caretaking, such as parents caring for their child's health and well-being (Bleakley et al., 2015; MeadowsOliver \& Hendrie, 2013). Or friends and members of the community caring for each other needs. Studies have found that content related to nurturance is effective in health communication (Bleakley et al., 2015). Affiliation was the second positive most often employed emotional appeal. To be concerned with maintaining good relationships with kin among other peers, to have friendship and social bonds, being a reciprocal and cooperative person, are attitudes and actions related to affiliation (Hetsroni 2000; Mogaji, 2016; Pollay, 1983). Sloan et al. (2020) studied the extent to which North American citizens feared the virus, and the results showed the subjects awareness about caring of others, especially family members, close friends, and elderly relatives. Since the beginning of the coronavirus outbreak, mass media campaigns have reinforced the idea of staying at home, to keep safe and save others whom one appreciates. Affiliation and nurturance are not far from this advice. Positive emotions appeals have featured more than negative ones in the sampled ads. Marketers know that positive emotions pose less risk than negative ones when used in brand communications (Chang \& Chang, 2014; Czarnecka \& Mogaji, 2019; Hornik, Ofir \& Rachamim, 2017; Marchegiani \& Phau, 2013; Wu et al., 2018). This observation is consistent with the results reported by Czarnecka \& Mogaji (2019), when studying advertising for financial services. They found those ads predominantly used positive emotional appeals, such as relief, security and excitement, while they seldom used negative appeals.

Sorrow was the third preferred emotional appeal resulting from the sample. It was likewise the most used negative emotion. According to the law of apparent reality, during stressful moments the recommendation it to be cautious while recurring to negative emotions, as they can be felt more intensely by consumers (Frijda, 1988). According to the theory, individuals may have experienced sorrowful ads with more intensity than those featuring emotions of affiliation or nurturance. As Mantovani \& Tazima (2016) argue, negative emotions have a stronger impact than positive emotions, an effect that can be true in a stressful situation such as the pandemic. Advertisers use negative emotional messages as sorrow to achieve a greater persuasive influence (Coleman, Royne \& Pounders, 2020; Coulter \& Pinto, 1995). This strategy is not without risks, as Berger and Milkman (2012) found that somber contents leads to less activation and decreases people's motivation to share content. Nostalgia replaced sorrow as the negative appeal of preference in the months after the pandemic started. Nostalgia is grounded in evocations from the personal past, as the individual recalls the way he used to be, memories made up of earlier events and emotions (Havlena \& Holak, 1991; Holbrook \& Schindler, 1991; Stern, 1992). Consumers long for the past when they encounter a loss of confidence in the future, or when reality changes unexpectedly in the present (Clarke \& Schmidt, 1995). Probably ad professionals 
and their clients draw upon nostalgia during early pandemic to engage with the consumers by referring to a better past, and project to a brighter future. For example, airline companies were talking about how amazing air travel was, and the joys of visiting attractive destinations before the lockdowns. These phenomena are consistent with Marchegiani \& Phau (2013), who argue that nostalgia is an effective emotional appeal to be adopted in advertising when people confront insecurities, as they become more conscious of the past and wish to remember it. Zhang et al. (2014) state that market insecurities give rise to a circumstance in which nostalgia is a suitable emotion to relate with consumers. Same authors suggest that sad contents in advertising causes empathy and emotional immersion among buyers.

Excitement was the fifth most frequently featured emotional appeal. This emotion is linked to pleasure, satire, wit, relief, positive mood, it provokes amusement, joy and fun (Chang \& Chang, 2014; Czarnecka \& Mogaji, 2019; Hornik, Ofir \& Rachamim, 2017; Li, 2019). According to Hornik, Ofir \& Rachamim (2017) and Li (2019) excitement is a strong emotional appeal to relate with the consumers. Czarnecka \& Mogaji (2019) noticed that excitement was frequent in loan adverts, as it projected joyful experiences referred to acquiring a new car, a holiday trip or home through bank financing. Chang \& Chang (2014) also identified that excitement works in ads for travel agencies, when linked to the expectation of visiting pleasant destinations during the holidays. Excitement in the sampled ads related to the enjoyment of spending time with friends, family or community members. An emotional appeal that followed excitement was pride. It was particularly present in those advertisements that told stories of strength and resilience, usually accompanied by epical scores, and connected to a spirit of patriotism and love for the homeland. This narrative style has been prevalent in ads during the pandemic (The Economist, 2020). Advertising cannot forget its social responsibility. Emotions are currently exacerbated by the coronavirus outbreak (Cowan, 2020; Huang \& Zhao, 2020). According to recent research, socially vulnerable members-Blacks, Hispanics, females, and youth-appeared to be at risk for suicidality during COVID-19 (Fitzpatrick, Harris \& Drawve, 2020). Advertising has a social responsibility, which can be directed on promoting consumer behaviors that leave a positive impact on their communities (Cowan, 2020; Huang \& Zhao, 2020). In a situation such as the pandemic, brand communication practitioners should make a thorough use of emotions, using this resource to contribute to society, aware of avoiding giving rise to harmful attitudes or practices. Specially in the near future, when Web 4.0 and 5.0 will favor the appeal to emotions among individuals (Almeida, 2017; Kotler, Kartajaya \& Setiawan, 2017).

A limitation of this study is that the sample was drawn from an archive of advertisements whose content and cataloging is not regulated, nor does it respond to criteria established a priori. Ads of the World is an open access web catalog where anyone related to the creative and advertising industry around the globe may display their work. It is a wellknown inventory among practitioners, one where agencies from all over the world exhibit their best creative work, although the norms with which they select each ad to be included in the inventory is not standardized.

This study opens the possibility for future research to deepen in the effectiveness of the sampled ads and show if the expected results were achieved within its target market. Li (2019) states that different emotional appeals can contribute to various affective responses between people and lead to particular communication outcomes. Turner (2007), argues that 
the success of a message depends on whether the emotion matches the audience so that the content is processed and not rejected. This statement coincides with Hong \& Zinkhan (1995) who explains that the emotion conveyed by the brand must synchronize the self-emotion perceived by each individual to be effective. The effects originating from diverse audience segmentations could be further analyzed. For example, Meyers-Levy \& Sternthal (1991) found that men and women differ in how information is treated, women exhibiting greater sensitivity than men while making judgments. It would be possible to analyze the emotional outcome of each advertisement among different genders, including its effect by age, cultural and market contexts. Another topic would relate to the concurrent use of positive and negative emotional appeals, as the research on this matter is not conclusive (Xie et al., 2004; Gross, 2008). Further research could also examine the creative process that marketing communications practitioners followed during when creating these advertisements, in such uncertain time as the early pandemic months. Taking into consideration any budget constrains from their clients, the challenge of having to produce the messages while in quarantine, and the stress caused by worrying about their own health and that of their special others. There is extensive literature on the motivation and factors that make up the advertising creative process (Turnbull \& Wheeler, 2017; Ahmad, Stufhaut \& Labianca, 2017; Vanden Bergh \& Stuhlfaut, 2006) however, it will be interesting to know how this takes place in peculiar circumstances as the COVID-19 pandemic.

\section{References}

Aaker, D.; Stayman, D. \& Hagerty, M. R (1986). Warmth in Advertising: Measurement, Impact and Sequence Effects, Journal of Consumer Research, 12 (4), 365-381.

Abele, A. E., \& Gendolla, G. H. (1999). Satisfaction Judgments in Positive and Negative Moods: Effects of Concurrent Assimilation and Contrast Producing Processes, Personality and Social Psychology Bulletin, 25 (7), 883-895.

Ahmad, W., Stufhaut, M., \& Labianca, J. (2017). Collaborative Dynamics of Creative Teams: Modeling Creative Process in Advertising Design. Business \& Economic Review, 9(4), 157-180.

Ahorsu, D. K., Lin, C. Y., Imani, V., Saffari, M., Griffiths, M. D., \& Pakpour, A. H. (2020). The fear of COVID-19 scale: Development and initial validation. International Journal of Mental Health and Addiction, 1-9.

Albers-Miller, N. D., \& Stafford, R. M. (1999). An international analysis of emotional and rational appeals in services vs goods advertising. Journal of Consumer Marketing, 16(1), 42-57. doi:10.1108/07363769910250769

Almeida, F. L. (2017). Concept and dimensions of web 4.0. International Journal of Computers \& Technology, 16(7), 7040-7046.

Basil, D. Z., Ridgeway N. M., \& Basil, M. D. (2006). Guilt Appeals: The Mediating Effect of Responsibility, Psychology and Marketing, 23 (12), 1035-54. doi:10.1002/mar.20145

Bhatia, T. K. (2019). Emotions and language in advertising. World Englishes, 38(3), 435-449.

Berger, J. \& Milkman K. L. (2012), What Makes Online Content Viral?, Journal of Marketing Research, 49 (2), 192-205.

Bleakley, A., Jordan, A. B., Hennessy, M., Glanz, K., Strasser, A., \& Vaala, S. (2015). Do emotional appeals in public service advertisements influence adolescents' 
intention to reduce consumption of sugar-sweetened beverages?. Journal of Health Communication, 20(8), 938-948.

Brennan, L., \& Binney, W. (2010). Fear, guilt, and shame appeals in social marketing. Journal of business Research, 63(2), 140-146.

Chang, W. Y., \& Chang, I. (2014). The influences of humorous advertising on brand popularity and advertising effects in the tourism industry. Sustainability, 6, 92059217.

Clarke, I., \& Schmidt, R. A. (1995). Beyond the service scape: The experience of place. Journal of Retailing and Consumer Services, 2(3), 149-162.

Coleman, J. T., Royne, M. B., \& Pounders, K. R. (2020). Pride, Guilt, and Self-Regulation in Cause-Related Marketing Advertisements. Journal of Advertising, 49(1), 34-60.

Coulter, R. \& Pinto, M. B. (1995), Guilt Appeals in Advertising: What Are Their Effects?,Journal of Applied Psychology, 80 (6), 697-705. doi:10.1037//00219010.80.6.697

Cowan, K. (2020). Survey results: Understanding people's concerns about the mental health impacts of the COVID-19 pandemic. London, United Kingdom: Academy of Medical Sciences.

Czarnecka, B., \& Mogaji, E. (2019). How are we tempted into debt? Emotional appeals in loan advertisements in UK newspapers. International Journal of Bank Marketing.

Deborah, A. S., \& Nicole, M. V. (2009). The Face of Need: Facial Emotion Expression on Charity Advertisements. Journal of Marketing Research, 46, 777-787.

Decrop, A. \& Derbaix C. (2010), Pride in Contemporary Sport Consumption: A Marketing Perspective. Journal of the Academy of Marketing Science, 38 (5), 586-603. doi:10.1007/s11747-009-0167-8

Dens, N., \& De Pelsmacker, P. (2010). Consumer Response to Different Advertising Ap-peals for New Products: The Moderating Influence of Branding Strategy and Product Category Involvement. Journal of Brand Management, 18, 50-65.

Drakulich, K. M. (2015). Concerns for self or family? Sources of and responses to altruistic fear. Journal of Interpersonal Violence, 30(7), 1168-1207

Durkin, S., Bayly, M., Brennan, E., Biener, L., \& Wakefield, M. (2018). Fear, sadness and hope: Which emotions maximize impact of anti-tobacco mass media advertisements among lower and higher SES groups?. Journal of Health Communication, 23(5), 445461.

Evans, A. I., Adamo, G. E., \& Czarnecka, B. (2019). European Destination managers ambivalence towards the use of shocking advertising. In Advances in Advertising Research X (205-214). Springer Gabler, Wiesbaden.

Faseur, T., \& Geuens, M. (2006). Different positive feelings leading to different ad evaluations: The case of coziness, excitement, and romance. Journal of Advertising, 35(4), 129-142.

Fitzpatrick, K. M., Harris, C., \& Drawve, G. (2020). Fear of COVID-19 and the mental health consequences in America. Psychological Trauma: Theory, Research, Practice, and Policy, Advance online publication. http://dx.doi.org/10.1037/tra0000924

Frijda, Nico H. (1986), The Emotions, Cambridge: Cambridge University Press.

Garfin, D. R., Silver, R. C., \& Holman, E. A. (2020). The novel coronavirus (COVID-2019) outbreak: Amplification of public health consequences by media exposure. Health Psychology. 34, http://dx.doi.org/10.1037/hea0000875 
Giachino, C., Stupino, M., Petrarulo, G., \& Bertoldi, B. (2017). Fear Appeals in Social Marketing: The Case of Anti-Speeding Video Advertisement "Mistakes". Journal of Customer Behaviour, 16, 61-74.

Gross, K. (2008). Framing persuasive appeals: Episodic and thematic framing, emotional response, and policy opinion. Political Psychology, 29(2), 169-192.

Grossman, M. \& Wood, W. (1993), Sex Differences in Intensity of Emotional Experience: A Social Role interpretation, Journal of Personality and Social Psychology, 65 (5), 1010-22.

Hagtvedt, H. \& Patrick, V. (2008). Art infusion: The influence of Visual Art on the Perception and Evaluation of Consumer Products. Journal of Marketing Research 45 (3), 379389.

Havlena, W. J., \& Holak, S. L. (1991). The good old days: observations on nostalgia and its role in consumer behavior. In R. H. Holman \& M. R. Solomon (Eds.), Advances in consumer research 18 (pp. 323-329). Provo, UT: Association for Consumer Research.

Hetsroni, A. (2000). The relationship between values and appeals in Israeli advertising: A smallest space analysis. Journal of Advertising, 29(3), 55-68.

Holbrook, M. B., \& Schindler, R. M. (1991). Echos of the dear departed past: some work in progress on nostalgia. In R. H. Holman \& M. R. Solomon (Eds.), Advances in consumer research 18 (pp. 330-333). Provo, UT: Association for Consumer Research.

Hong, J. W., \& Zinkhan, G. M. (1995). Self-concept and advertising effectiveness: The influence of congruency, conspicuousness, and response mode. Psychology \& Marketing, 12(1), 53-77.

Hornik, J., Ofir, C., \& Rachamim, M. (2017). Advertising Appeals, Moderators, And Impact on Persuasion. Journal of Advertising Research, 57(3), 305-318. doi:10.2501/jar2017-017 http://angusreid.org/coronavirus/

Huang, Y., \& Zhao, N. (2020). Generalized anxiety disorder, depressive symptoms and sleep quality during COVID-19 epidemic in China: A web-based cross-sectional survey. MedRXiv. http://dx.doi.org/10.1101/ 2020.02.19.20025395

Johar, J. S., \& Sirgy, M. J. (1991). Value-expressive versus utilitarian advertising appeals: When and why to use which appeal. Journal of advertising, 20(3), 23-33.

Kemp, E., Kennett-Hensel, P. A., \& Kees, J. (2013). Pulling on the heartstrings: Examining the effects of emotions and gender in persuasive appeals. Journal of Advertising, 42(1), 69-79.

Kotler, P. (2003). Marketing management (11th ed.). New Jersey: Prentice Hall.

Kotler, P., \& Armstrong, G. (1991). Principles of marketing (5th ed.). NJ: Prentice Hall Inc.

Kotler, P.; Kartajaya, H. \& Setiawan, I. (2017), Marketing 4.0, Moving from traditional to digital, Wiley, New Jersey.

Krippendorff, K. (2019). The changing landscape of content analysis: Reflections on social construction of reality and beyond. Communication \& Society, 47, 1.

Krishen, A. S., \& Bui, M. (2015). Fear Advertisements: Influencing Consumers to Make Better Health Decisions. International Journal of Advertising, 34, 533-548.

Leder, H.; Belke B.; Oeberst, A \& Augustin, D. (2004). A Model of Aesthetic Appreciation and Aesthetic Judgments. British Journal of Psychology, 95 (4), 489-508.

Li, S (2019). Emotional Appeals in Tourism TV Commercials: A Psycho-Physiological Study, Journal of Hospitality \& Tourism Research, 43(6), 783-806 
Lin, L-Y. (2011). The impact of advertising appeals and advertising spokespersons on advertising attitudes and purchase intentions. African Journal of Business Management, 5(21), 8446-8457.

Mantovani, D., \& Tazima, D. I. (2016). Visual art and regulatory fit messages on consumer evaluations. Revista de Administração de Empresas, 56(2), 152-165.

Marchegiani, C., \& Phau, I. (2013). Personal and historical nostalgia. A comparison of common emotions. Journal of Global Marketing, 26(3), 137-146.

Meadows-Oliver, M., \& Hendrie, J. (2013). Expanded back to sleep guidelines. Pediatric Nursing, 39, 40-49.

Mejova, Y. \& Kalimeri, K. (2020). Advertisers Jump on Coronavirus Bandwagon: Politics, News, and Business, arXiv preprint arXiv:2003.00923.

Meyers-Levy, J., \& Sternthal, B. (1991). Gender differences in the use of message cues and judgments. Journal of Marketing Research, 28(1), 84-98.

Mogaji, E. (2016). Emotional appeals in UK banks' print advertisement (Doctoral dissertation, University of Bedfordshire, Bedfordshire, UK). Retrieved from http://hdl.handle.net/10547/622103.

Nabi, R. L. (2003). Exploring the framing effects of emotion: Do discrete emotions differentially influence information accessibility, information seeking, and policy preference? Communication Research, 30, 224-247.

Neuendorf K. A. (2018). Content analysis and thematic analysis. In Brough, P. (Ed.). (2018). Advanced research methods for applied psychology: design, analysis and reporting. Routledge.

Panda, T. K., Panda, T. K., \& Mishra, K. (2013). Does emotional appeal work in advertising? The rationality behind using emotional appeal to create favorable brand attitude. IUP Journal of Brand Management, 10(2), 7.

Parvathi, M. \& Mariselvi, R. (2017). A bird's eye on the evolution - Web 1.0 to Web 5.0: Lib 1.0 to Lib 5.0. International Journal of Advanced Research Trends in Engineering and Technology (IJARTET), 4(4), 167-176.

Pinto, M. B., \& Yagnik, A. (2017). Fit for life: A content analysis of fitness tracker brands use of Facebook in social media marketing. Journal of Brand Management, 24(1), 49-67.

Poels, K., \& Dewitte, S. (2019). The role of emotions in advertising: a call to action. Journal of Advertising, 48(1), 81-90.

Polanska, K. (2014). Social Media in Modern Business. European Scientific Journal, 1(1), 335-345.

Pollay, R. W. (1983). Measuring the cultural values manifest in advertising. Current issues and research in advertising, 6(1), 71-92.

Reichert, T., \& Lambiase, J. (Eds.). (2014). Sex in advertising: Perspectives on the erotic appeal. Routledge.

Rhodes, N. "Fear-Appeal Messages: Message Processing and Affective Attitudes." Communi cation Research 64, 2 (2015): 1-24.

Rochford, E. D. (2011). Communication studies. USA, NewYork, Bloomington: iUniverse, Inc. Royo-Vela, M. (2005). Emotional and Informational Content in Commercials, Journal of Current Issues and Research in Advertising, (Fall), 13-38.

Sloan, M. M., Haner, M., Graham, A., Cullen, F. T., Pickett, J. T., \& Jonson, C. L. (2020). Pandemic Emotions: The Extent, Correlates, and Mental Health Consequences of Personal and Altruistic Fear of COVID-19. Working Paper, University of South Florida. 
Stern, B. B. (1992). Historical and personal nostalgia in advertising text: The fin de siècle effect. Journal of Advertising, 24(4), 11-22.

The Economist (2020, June 20). The advertising business is becoming less cyclical-and more concentrated. Retrieved from: Https://www.economist.com/business/2020/06/25/the-advertising-business-isbecoming-less-cyclical-and-more-concentrated.

Tian, Y., Galery, T., Dulcinati, G., Molimpakis, E., \& Sun, C. (2017). Facebook sentiment: Reactions and emojis. In Proceedings of the Fifth International Workshop on Natural Language Processing for Social Media (pp. 11-16).

Turnbull, S., \& Wheeler, C. (2017). The advertising creative process: A study of UK agencies. Journal of Marketing Communications, 23(2), 176-194.

Turner, M. M. (2007). Using emotion in risk communication: The anger activism model. Public Relations Review, 33(2), 114-119.

Vanden Bergh, B., \& Stuhlfaut, M. (2006). Is advertising creativity primarily an individual or a social process?. Mass communication \& society, 9(4), 373-397.

Vargas-Bianchi, L., \& Mensa, M. (2020). Do you remember me? Women sexual objectification in advertising among young consumers. Young Consumers. 21 (1), 77 90

Wang, C. L. (2008). Gender Difference in Responding to Sad Emotional Appeal: A Moderated Mediation Explanation, Journal of Nonprofit and Public Sector Marketing, 19 (1), 55-70.

Wu, C., Sundiman, D., Kao, S. C., \& Chen, C. H. (2018). Emotion induction in click intention of picture advertisement: a field examination. Journal of Internet Commerce, 17(4), 356-382.

Xie, T., Donthu, N., Lohtia, R., \& Osmonbekov, T. (2004). Emotional appeal and incentive offering in banner advertisements. Journal of Interactive Advertising, 4(2), 30-37.

Zarzosa, J., \& Huhmann, B. A. (2019). Measures of aesthetic dimensions and reactions in advertising. International Journal of Advertising, 38(2), 258-275.

Zhang, H., Sun, J., Liu, F., \& Knight, J. G. (2014). Be rational or be emotional: advertising appeals, service types and consumer responses. European Journal of Marketing, 48 (11/12), 2105-2126.

Zheng, M. X. (2020). When and Why Negative Emotional Appeals Work in Advertising: A Review of Research. Open Journal of Social Sciences, 8, 7-16. 